\title{
Role of the STK15 Phe31Ile polymorphism in renal cell carcinoma
}

\author{
CHRISTINE G. HAMMERSCHMIED ${ }^{1}$, ROBERT STOEHR ${ }^{1}$, BERNHARD WALTER ${ }^{1}$, WOLF F. WIELAND ${ }^{1}$, \\ ARNDT HARTMANN $^{2}$, HAGEN BLASZYK ${ }^{3}$ and STEFAN DENZINGER ${ }^{1}$ \\ ${ }^{1}$ Department of Urology, ${ }^{2}$ Institute of Pathology, University of Regensburg, Germany; \\ ${ }^{3}$ Department of Pathology, University of Vermont College of Medicine, Burlington, VT, USA
}

Received June 14, 2006; Accepted September 5, 2006

\begin{abstract}
The search of inherited cancer susceptibility factors is an important subject in cancer epidemiology. Analyses of single nucleotide polymorphisms (SNP) in various genes revealed a correlation between the presence of specific allelic variants and cancer predisposition in diverse malignancies. STK15 is an important protein in control of the integrity of the mitotic spindle apparatus and genomic stability. We analysed the distribution of the functionally important T91A SNP in the STK15 gene in a cohort of renal cell carcinoma (RCC) patients and compared it to the distribution in a control group without malignancies. DNA from formalin-fixed, paraffinembedded healthy renal tissue (RCC patients) or peripheral blood samples (control group) was isolated according to standard protocols. Allelic variant of STK15 nucleotide 91 was determined using restriction fragment length polymorphism (RFLP) analysis. Overall, 156 RCC patients and 158 patients without any malignancy were analysed. The distribution of the STK15 SNP in RCC patients (T/T, 58.97\%; A/T, 36.53\%; A/A, $4.49 \%$ ) did not significantly differ from that of the control group (T/T, 51.27\%; A/T, 41.14\%; A/A, 7.59\%). There was also no correlation between genotype and tumour grade or stage or other histopathological characteristics of the tumours. This first analysis of the STK15 T91A SNP in RCC patients revealed no correlation between a certain allelic variant and an increased risk for RCC.
\end{abstract}

\section{Introduction}

The yearly incidence of renal cell carcinoma (RCC) in Europe is 42,000 , about $30 \%$ of them are already metastasized at that time, while in additional $30-40 \%$ of cases metastases are predetermined to form. The only curative therapy at present is tumour nephrectomy. Current adjuvant therapies based on

Correspondence to: Dr Christine Hammerschmied, Department of Urology, University of Regensburg, Franz Josef Strauss Allee 11, D-93042 Regensburg, Germany

E-mail: christine.hammerschmied@klinik.uni-regensburg.de

Key words: renal cell carcinoma, STK15, Aurora A, Aurora 2, $B T A K, A R K 1$, single nucleotide polymorphism, restriction fragment length polymorphism, PCR cytokines like interleukin-2 and/or interferon- $\alpha$ are applied only to metastatic diseases due to severe side-effects, but only a minority of cases responds $(1,2)$. Therefore, about $60 \%$ $(25,000)$ of patients die from an aggressive course of disease (3).

Among renal cancers, there are a number of inherited cancer syndromes, i.e., von Hippel-Lindau disease, hereditary papillary renal cancer, hereditary leiomyomatosis and RCC, Birt-Hogg-Dubé syndrome, Tuberous sclerosis and constitutional chromosome 3 translocation. In most instances certain oncogenes or tumour suppressor genes are known to be affected and the respective germ line mutations were identified (4). In contrast, in sporadic RCC distinct chromosomal aberrations were detected, e.g., combined gains and losses of various chromosomal regions.

The association of sporadic RCC with characteristic chromosomal aberrations is well established (5-11), but the underlying mechanisms are still unknown. The losses and gains of specific chromosomal regions suggest a mechanism of erroneous chromosomal segregation. In this process, Aurora kinases were shown to play a fundamental role and all of them could be linked to oncogenesis and cancer progression (12). STK15, also known as Aurora A, Aurora 2 or BTAK, is upregulated at the onset of mitosis (13). It is mainly involved in centrosome maturation and spindle assembly, and recently was identified as cancer susceptibility gene $(14,15)$. An overexpression linked to chromosomal instability and clinically aggressive disease was found in various malignancies including bladder cancer, hepatocellular carcinoma and esophageal squamous cell carcinoma $(12,16-19)$. Compared to adjacent renal tissue, strong expression of STK15 was also shown in sporadic RCC (20).

A certain type of sequence variation, namely a single base substitution within the sequence of a gene or a promoter is called single nucleotide polymorphism (SNP). In most cases, these alterations are silent, i.e., do not affect protein function or expression. However, these base substitutions can also affect promoter sequences, resulting in altered protein expression. Moreover, base substitution within a gene may lead to replacement of a functionally important amino acid, resulting in altered secondary structure and therefore modified properties. Those proteins might act in a different way. Examination of various SNPs has lead to the identification of numerous cancer susceptibility genes modifying the personal risk of cancer disease (21). 
The only functional polymorphism known in STK15 to date is caused by single nucleotide substitution at gene sequence position $91(\mathrm{~T} \rightarrow \mathrm{A})$ and leads to replacement of Phe by Ile in amino acid sequence position 31 (22). In several studies investigating breast or ovarian cancer, an association of this polymorphism to cancer risk could be demonstrated $(23,24)$. To our best knowledge, there is currently no study regarding the role of this STK15 polymorphism in sporadic RCC.

Therefore we analysed the distribution of this SNP in sporadic RCC patients and a healthy control group to investigate a possible association with RCC risk.

\section{Materials and methods}

Samples. One hundred and fifty-six formalin-fixed and paraffinembedded tissue samples from RCC patients obtained by tumour nephrectomy archived at the Institute of Pathology, University of Regensburg (Germany) and the Institute of Pathology University of Vermont, Burlington (VT, USA) were investigated and compared to 158 samples from a control group consisting of patients without any malignancies acquired at the Department of Urology, St. Josef Hospital, University of Regensburg. The cases and controls were similar in regard to sex and age distribution. Histological parameters of the corresponding tumours of RCC patients are shown in Table I. All tumours were diagnosed according to the 2004 WHO classification of renal cell carcinoma (4) and staged according to the TNM system $(25,26)$. Prior IRB approval was obtained through the participating institutions.

Tissue microdissection and DNA isolation. DNA was extracted from manually microdissected normal renal tissue (cases) and peripheral blood (controls) by the 'PCR Template Purification Kit' (Roche Diagnostics, Mannheim, Germany) according to the manufacturer's instructions.

STK15 SNP analysis. SNP analysis was carried out by restriction fragment length polymorphism (RFLP) analysis of exon 3, which contains an ApoI restriction site (5'-RAATTY-3', $\mathrm{R}$, purine base; $\mathrm{Y}$, pyrimidine base) in case of the base adenine (italic) being located at position 91. Results were confirmed by sequence analysis to ensure correct interpretation especially of heterozygous samples.

$P C R$. SNP region was amplified by PCR using the primers obtained from Proligo (Paris, France) shown in Table II in a total volume of $25 \mu 1$ containing approximately $100 \mathrm{ng}$ DNA, $0.2 \mathrm{mM}$ dNTP (Roche Diagnostics), $0.18 \mu \mathrm{M}$ primers and $0.0025 \mathrm{U} / \mu 1$ GoTaq (Promega, Mannheim, Germany). The thermal cycling conditions were as follows: initial denaturation for 2 min at $95^{\circ} \mathrm{C}, 35$ cycles of denaturation at $95^{\circ} \mathrm{C}$, annealing at $50^{\circ} \mathrm{C}$ for $1 \mathrm{~min}$, elongation at $72^{\circ} \mathrm{C}$ for $1 \mathrm{~min}$ and final primer extension at $72^{\circ} \mathrm{C}$ for $10 \mathrm{~min}$.

PCR products were incubated overnight with $5 \mathrm{U}$ ApoI (New England Biolabs, Frankfurt/Main, Germany) and $100 \mu \mathrm{g} / \mathrm{ml} \mathrm{BSA}$ at $37^{\circ} \mathrm{C}$ in a total volume of $30 \mu 1$ to ensure complete digestion. Restriction fragments were separated by agarose gel electrophoresis $(2.5 \%, \mathrm{TBE})$ for $60 \mathrm{~min}$ at $110 \mathrm{~V}$. Visualization of bands was performed by ethidium bromide staining using UV-light. According to the experimental design,
Table I. Histopathological features of the tumours.

\begin{tabular}{|c|c|}
\hline Tumour type & No. \\
\hline Clear cell & 101 \\
\hline Papillary & 30 \\
\hline Chromophobe & 13 \\
\hline Oncocytoma & 4 \\
\hline Spindle cell & 2 \\
\hline Undifferentiated & 3 \\
\hline Unclear & 2 \\
\hline Ductus bellini & 1 \\
\hline Eosinophil & 2 \\
\hline Sarcomatoid & 2 \\
\hline Stage & No. \\
\hline Stage 1 & 87 \\
\hline Stage 2 & 12 \\
\hline Stage 3 & 26 \\
\hline Stage 4 & 14 \\
\hline Unknown stage & 13 \\
\hline $\mathrm{pT}$ & No. \\
\hline $\mathrm{T} 1 \mathrm{x}$ & 1 \\
\hline T1a & 61 \\
\hline $\mathrm{T} 1 \mathrm{~b}$ & 36 \\
\hline $\mathrm{T} 2$ & 15 \\
\hline $\mathrm{T} 3 \mathrm{x}$ & 2 \\
\hline $\mathrm{T} 3 \mathrm{a}$ & 21 \\
\hline $\mathrm{T} 3 \mathrm{~b}$ & 16 \\
\hline $\mathrm{pN}$ & No. \\
\hline No & 132 \\
\hline $\mathrm{N} 2$ & 8 \\
\hline $\mathrm{Nx}$ & 12 \\
\hline $\mathrm{pM}$ & No. \\
\hline M0 & 131 \\
\hline M1 & 8 \\
\hline $\mathrm{Mx}$ & 13 \\
\hline Grade & No. \\
\hline G1 & 43 \\
\hline $\mathrm{G} 2$ & 89 \\
\hline G3 & 19 \\
\hline Gx & 1 \\
\hline
\end{tabular}


Table II. STK15 SNP PCR primers. Sense primer was also used for sequence analysis.

\begin{tabular}{llcr}
\hline Primer & \multicolumn{1}{c}{ Sequence $5^{\prime} \rightarrow 3^{\prime}$} & Annealing temperature & Product length \\
\hline Sense & CTCAATATATTCATCTTTTGC & $50^{\circ} \mathrm{C}$ & $170 \mathrm{bp}$ \\
Antisense & AGGACACAAGACCCGCTG & & \\
\hline
\end{tabular}

$\mathbf{A}$

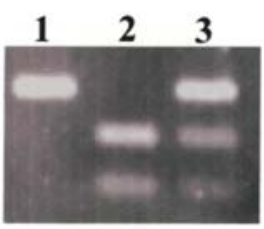

B

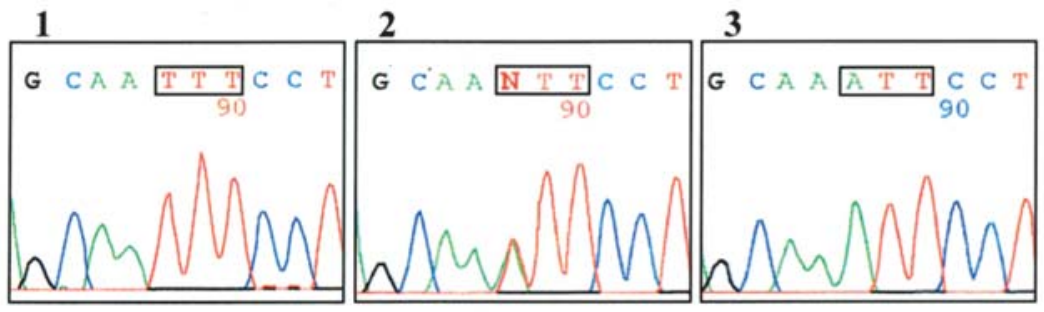

C

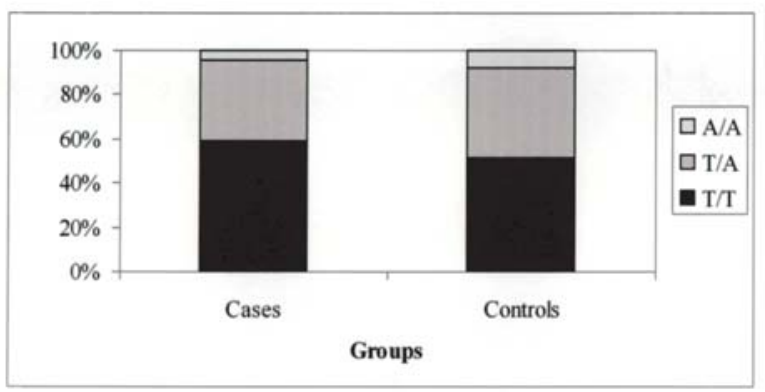

Figure 1. Representative examples for SNP results. A, Analysis by RFLP method: lane 1, T/T; lane 2, A/T; lane 3, A/A. B, Sequence analysis: lane 1, T/T; lane 2, T/A; lane 3, A/A. Boxes indicate codon 31. C, Bar chart of genotype distributions in cases and controls.

a band at $170 \mathrm{bp}$ indicates the T-allele, bands at 109 and $61 \mathrm{bp}$ the A-allele. Consequently, samples only showing the $170 \mathrm{bp}$ or 109 and $61 \mathrm{bp}$ band were interpreted homozygous for the $\mathrm{T}$ - or A-allele respectively, while samples containing all three bands were interpreted to be heterozygous.

Sequence analysis. Results were confirmed by sequencing of the SNP region of randomly chosen samples after purification of the PCR products by polyethylene glycol precipitation (27) in a PTC100 Thermocycler using the PRISM Ready Dye Terminator Cycle Sequencing Kit (Applied Biosystems, Weiterstadt, Germany) according to the manufacturer's instructions and an Applied Biosystems 373 sequencer. Primer sequence is shown in Table II (Proligo).

Statistical analysis. $\chi^{2}$ statistics (two-sided Fisher's exact tests) were used to evaluate case-control differences in the distribution of genotypes (SPSS 13.0). p<0.05 was interpreted as statistically significant.

\section{Results}

Genotype distribution was 92/156 (58.97\%) T/T, 57/156 (36.53\%) T/A, 7/156 (4.49\%) A/A in cases and was 81/158 (51.27\%) T/T, 65/158 (41.14\%) T/A, 12/158 (7.59\%) A/A in controls. Although there were a higher amount of T/T and less $\mathrm{T} / \mathrm{A}$ and $\mathrm{A} / \mathrm{A}$ genotypes in cases, these differences were not significant ( $\mathrm{p}=0.311$, Fig. 1 ). We could not find any significant correlation of genotypes and histologic type $(\mathrm{p}=0.672)$, tumour stage $(p=0.286)$, or grade $(p=0.936)$ among cases. Sequencing samples of each genotype confirmed the RFLP results. Representative examples for both methods are shown in Fig. 1. To exclude any bias caused by the composition of our control group, we compared genotype distributions of our controls to those of several other studies (15) on STK15 polymorphisms in Caucasians and found very similar allele frequencies.

\section{Discussion}

Chromosomal imbalances occur frequently in sporadic RCC, and are well described $(5-7,28,29)$. Studies investigating several other malignancies could link those imbalances to an impaired segregation machinery, with STK15 being a key component (12,30-32). STK15 overexpression in several cancers correlates with the functional STK15 Phe31Ile SNP, as shown by Ewart-Toland and colleagues (22). Currently, there is no published data regarding the role of the STK15 Phe31Ile SNP in sporadic RCC.

Our analysis of 156 RCC cases and 158 controls revealed no significant differences regarding genotype distribution 
between the groups. Therefore, contrary to findings in other malignancies, we could not link a certain genotype to enhanced cancer predisposition $(15,22)$. Also, no correlation to histopathological features could be detected.

One might speculate that the reported overexpression of STK15 protein in RCC (20) cannot be attributed to the STK15 Phe31Ile polymorphism, but possibly is due to erroneous periodic destabilization and degradation of the protein by the proteasome (33-36). As many mitotic proteins, STK15 is regulated by periodic ubiquitin-dependent proteolysis at the end of mitosis. The protein holds two domains needed for recognition by Cdh-1, a C-terminal destruction box (D-box) and a short region in the A box II, which is highly conserved among vertebrates. Mutation and deletion analyses have shown that dephosphorylation of Ser51 in this amino acid sequence could control the timing of destruction $(34,35)$. Moreover, a novel regulator of STK15, Aurora A kinase interacting protein (AIP), has been described and might also target the protein for proteasomal degradation (33). To our knowledge, currently there are no reports of studies concerning a possible STK15 deregulation in sporadic RCC.

Recently, STK15 was shown to be a downstream target of MAPK1/ERK2 pathway in pancreatic cancer (37). Downregulation of MAPK1/ERK2 induced by exogenous overexpression of DUSP6 in pancreatic cancer cells resulted in reduction of STK15 expression via knockdown of ETS2. Given the constitutive activation of ERKs in several renal cancer cell lines (38), this is another possible mechanism to consider.

An additional common cause of elevated STK15 expression is amplification of the STK15 gene region, 20q13 (17,39-41). This mechanism is unlikely in RCC, as Ehara and colleagues detected STK15 overexpression using immunohistochemistry predominantly in clear cell RCC $(12,20)$, known to lack chromosome 20 gains $(6,7,29)$.

To date, many SNP analyses were done on sporadic RCC. Polymorphic variants of genes involved in DNA repair (e.g., XRCC1, CHEK2), metabolism (GLUT1) or cell cycle (cyclin D1) seem to influence the susceptibility for sporadic RCC (42-45). Considering the important function of the kidney in detoxification of exogenous noxae, the analysis of detoxifying genes like $\mathrm{NAD}(\mathrm{P}) \mathrm{H}$ quinone oxidoreductase 1 (NQO1) is expected to provide deeper insights into RCC predisposition as was shown for enzymes activating procarcinogenic chemical compounds such as CYP1B1 (46).

In summary, this first analysis of the STK15 Phe31Ile polymorphism in sporadic RCC revealed no association between a certain allelic variant and an increased cancer risk.

\section{Acknowledgements}

We thank Ms. Kerstin Reher for excellent technical assistance. Professor Wolf F. Wieland, head of the institute, is thanked for constant scientific and financial support.

\section{References}

1. Atzpodien J, Kirchner H, Jonas U, et al: Interleukin-2- and interferon alfa-2a-based immunochemotherapy in advanced renal cell carcinoma: a Prospectively Randomized Trial of the German Cooperative Renal Carcinoma Chemoimmunotherapy Group (DGCIN). J Clin Oncol 22: 1188-1194, 2004.
2. Negrier S, Escudier B, Lasset C, et al: Recombinant human interleukin-2, recombinant human interferon alfa-2a, or both in metastatic renal-cell carcinoma. Groupe Francais d'Immunotherapie. N Engl J Med 338: 1272-1278, 1998.

3. Ljungberg B: Prognostic factors in renal cell carcinoma. Urologe A 43 (Suppl 3): 119-120, 2004.

4. Grignon DJ, Eble JN, Bonsib SN, et al: Tumours of the kidney. In: Pathology and Genetics of Tumours of the Urinary System and Male Genital Organs. Eble JN, Sauter G, Epstein JI and Setershenn IA (eds). IARC Press, Lyon, pp10-34, 2004.

5. Bugert P, Gaul C, Weber K, Herbers J, Akhtar M, Ljungberg B and Kovacs G: Specific genetic changes of diagnostic importance in chromophobe renal cell carcinomas. Lab Invest 76: 203-208, 1997.

6. Kovacs G: Molecular differential pathology of renal cell tumours. Histopathology 22: 1-8, 1993.

7. Kovacs G, Szucs S, De Riese W and Baumgartel H: Specific chromosome aberration in human renal cell carcinoma. Int $\mathrm{J}$ Cancer 40: 171-178, 1987.

8. Palmedo G, Fischer J and Kovacs G: Fluorescent microsatellite analysis reveals duplication of specific chromosomal regions in papillary renal cell tumors. Lab Invest 77: 633-638, 1997.

9. Speicher MR, Schoell B, Du Manoir S, et al: Specific loss of chromosomes $1,2,6,10,13,17$, and 21 in chromophobe renal cell carcinomas revealed by comparative genomic hybridization. Am J Pathol 145: 356-364, 1994.

10. Sanjmyatav J, Schubert J and Junker K: Comparative study of renal cell carcinoma by $\mathrm{CGH}$, multicolor-FISH and conventional cytogenic banding analysis. Oncol Rep 14: 1183-1187, 2005.

11. Junker K, Moravek P, Podhola M, Weirich G, Hindermann W, Janitzky V and Schubert J: Genetic alterations in metastatic renal cell carcinoma detected by comparative genomic hybridization: correlation with clinical and histological data. Int J Oncol 17: 903-908, 2000.

12. Katayama H, Brinkley WR and Sen S: The Aurora kinases: role in cell transformation and tumorigenesis. Cancer Metastasis Rev 22: 451-464, 2003.

13. Adams RR, Carmena M and Earnshaw WC: Chromosomal passengers and the (aurora) ABCs of mitosis. Trends Cell Biol 11: 49-54, 2001.

14. Dutertre $S$, Descamps $S$ and Prigent $C$ : On the role of aurora-A in centrosome function. Oncogene 21: 6175-6183, 2002.

15. Ewart-Toland A, Dai Q, Gao YT, et al: Aurora-A/STK15 T+91A is a general low penetrance cancer susceptibility gene: a metaanalysis of multiple cancer types. Carcinogenesis 26: 1368-1373, 2005.

16. Miyoshi Y, Iwao K, Egawa C and Noguchi S: Association of centrosomal kinase STK15/BTAK mRNA expression with chromosomal instability in human breast cancers. Int J Cancer 92: 370-373, 2001.

17. Sen S, Zhou H, Zhang RD, et al: Amplification/overexpression of a mitotic kinase gene in human bladder cancer. J Natl Cancer Inst 94: 1320-1329, 2002.

18. Jeng YM, Peng SY, Lin CY and Hsu HC: Overexpression and amplification of Aurora-A in hepatocellular carcinoma. Clin Cancer Res 10: 2065-2071, 2004.

19. Tong T, Zhong Y, Kong J, et al: Overexpression of Aurora-A contributes to malignant development of human esophageal squamous cell carcinoma. Clin Cancer Res 10: 7304-7310, 2004.

20. Ehara H, Yokoi S, Tamaki M, et al: Expression of mitotic Aurora/ Ipl1p-related kinases in renal cell carcinomas: an immunohistochemical study. Urol Res 31: 382-386, 2003.

21. Erichsen HC and Chanock SJ: SNPs in cancer research and treatment. Br J Cancer 90: 747-751, 2004.

22. Ewart-Toland A, Briassouli P, De Koning JP, et al: Identification of Stk6/STK15 as a candidate low-penetrance tumor-susceptibility gene in mouse and human. Nat Genet 34: 403-412, 2003.

23. Dai Q, Cai QY, Shu XO, et al: Synergistic effects of STK15 gene polymorphisms and endogenous estrogen exposure in the risk of breast cancer. Cancer Epidemiol Biomarkers Prev 13: 2065-2070, 2004.

24. Dicioccio RA, Song H, Waterfall C, et al: STK15 polymorphisms and association with risk of invasive ovarian cancer. Cancer Epidemiol Biomarkers Prev 13: 1589-1594, 2004.

25. Sobin LH and Wittekind C: TNM classification of malignant tumors. Wiley \& Sons, 2002.

26. Greene LF PD, Fleming D, Firtz A, Batch M, Haller DG and Morrow M: American Joint Committee on Cancer (AJCC). Cancer Staging Manual. Springer-Verlag, 2002. 
27. Stoehr R, Krieg RC, Knuechel R, et al: No evidence for involvement of beta-catenin and APC in urothelial carcinomas. Int J Oncol 20: 905-911, 2002.

28. Kovacs A, Storkel S, Thoenes W and Kovacs G: Mitochondrial and chromosomal DNA alterations in human chromophobe renal cell carcinomas. J Pathol 167: 273-277, 1992.

29. Kovacs G and Frisch S: Clonal chromosome abnormalities in tumor cells from patients with sporadic renal cell carcinomas. Cancer Res 49: 651-659, 1989.

30. Fraizer GC, Diaz MF, Lee IL, Grossman HB and Sen S: Aurora-A/STK15/BTAK enhances chromosomal instability in bladder cancer cells. Int J Oncol 25: 1631-1639, 2004.

31. Yamamoto Y, Matsuyama H, Kawauchi S, et al: Biological characteristics in bladder cancer depend on the type of genetic instability. Clin Cancer Res 12: 2752-2758, 2006.

32. Zhou H, Kuang J, Zhong L, et al: Tumour amplified kinase STK15/BTAK induces centrosome amplification, aneuploidy and transformation. Nat Genet 20: 189-193, 1998.

33. Kiat LS, Hui KM and Gopalan G: Aurora-A kinase interacting protein (AIP), a novel negative regulator of human Aurora-A kinase. J Biol Chem 277: 45558-45565, 2002.

34. Castro A, Arlot-Bonnemains Y, Vigneron S, Labbe JC, Prigent C and Lorca T: APC/Fizzy-Related targets Aurora-A kinase for proteolysis. EMBO Rep 3: 457-462, 2002.

35. Littlepage LE and Ruderman JV: Identification of a new APC/C recognition domain, the A box, which is required for the Cdh1dependent destruction of the kinase Aurora-A during mitotic exit. Genes Dev 16: 2274-2285, 2002.

36. Honda K, Mihara H, Kato Y, et al: Degradation of human Aurora2 protein kinase by the anaphase-promoting complex-ubiquitinproteasome pathway. Oncogene 19: 2812-2819, 2000.

37. Furukawa T, Kanai N, Shiwaku HO, Soga N, Uehara A and Horii A: AURKA is one of the downstream targets of MAPK1/ ERK2 in pancreatic cancer. Oncogene 25: 4831-4839, 2006.
38. Horiguchi A, Oya M, Marumo K and Murai M: STAT3, but not ERKs, mediates the IL-6-induced proliferation of renal cancer cells, ACHN and 769P. Kidney Int 61: 926-938, 2002.

39. Sen S, Zhou H and White RA: A putative serine/threonine kinase encoding gene BTAK on chromosome 20q13 is amplified and overexpressed in human breast cancer cell lines. Oncogene 14: 2195-2200, 1997.

40. Tanner MM, Grenman S, Koul A, et al: Frequent amplification of chromosomal region 20q12-q13 in ovarian cancer. Clin Cancer Res 6: 1833-1839, 2000.

41. Sakakura C, Hagiwara A, Yasuoka R, et al: Tumour-amplified kinase BTAK is amplified and overexpressed in gastric cancers with possible involvement in aneuploid formation. Br J Cancer 84: 824-831, 2001.

42. Hirata H, Hinoda Y, Matsuyama $\mathrm{H}$, et al: Polymorphisms of DNA repair genes are associated with renal cell carcinoma. Biochem Biophys Res Commun 342: 1058-1062, 2006.

43. Cybulski C, Gorski B, Huzarski T, et al: CHEK2 is a multiorgan cancer susceptibility gene. Am J Hum Genet 75: 1131-1135, 2004.

44. Page T, Hodgkinson AD, Ollerenshaw M, Hammonds JC and Demaine AG: Glucose transporter polymorphisms are associated with clear-cell renal carcinoma. Cancer Genet Cytogenet 163: 151-155, 2005.

45. Yu J, Habuchi T, Tsuchiya N, et al: Association of the cyclin D1 gene G870A polymorphism with susceptibility to sporadic renal cell carcinoma. J Urol 172: 2410-2413, 2004.

46. Sasaki M, Tanaka Y, Okino ST, et al: Polymorphisms of the CYP1B1 gene as risk factors for human renal cell cancer. Clin Cancer Res 10: 2015-2019, 2004. 